\title{
TORTO ARADO: A IMPORTÂNCIA DE NARRATIVAS DE MULHERES NEGRAS NA (RE) CONSTIUIÇÃO DE SUAS IDENTIDADES E PROTAGONISMO
}

\author{
TORTO ARADO: LA IMPORTANCIA DE LAS NARRATIVAS DE LAS MUJERES NEGRAS \\ EN LA (RE) CONSTITUCIÓN DE SUS IDENTIDADES Y PROTAGONISMO
}

\author{
Leonilda Paciente Luz ${ }^{1}$ \\ Epaminondas de Matos Magalhães ${ }^{2}$
}

Recebido em 15/10/2021

Aceito em 30/11/2021

Resumo: A obra Torto Arado (2019), de Itamar Vieira Junior, traz reflexões acerca de feridas que ainda estão abertas e ainda causam dores pelas mazelas escravistas e seus reflexos, sejam eles no campo individual, cultural, políticos ou ideológicos. O fato é que as políticas, os programas e todas as medidas contrárias as discriminações com efeitos devastadores provocados pela colonização continuam presentes na sociedade brasileira. Assim o trabalho analisa as experiências de resistência das mulheres negras protagonizadas na obra referenciada, cujas personagens se fortalecem descontruindo preconceitos e fazendo a (re) construção da identidade da mulher negra que reivindica contar a sua própria história, oriunda de outros lugares de enunciação que traga um sentimento de pertencimento a uma cultura que foi aprisionada e rebaixada pela visão eurocêntrica. Assim, considera-se no romance, primeiramente a relevância da literatura enquanto instrumento de resistência, na luta contra as injustiças raciais e as desigualdades de gêneros. Em seguida, pelo viés das narrativas das protagonistas do romance em questão, que retrata o percurso percorrido pelas personagens femininas para o fortalecimento de suas identidades. Por fim, busca-se o encontro com as vozes da ancestralidade que traz sentido a sua existência e o prazer da (re) descoberta de uma mulher segura de si e mais forte. As perspectivas teóricas que permeiam o estudo são as obras de: Spivak (2010), Hall (2007), Said (2001) Duarte (2005), Adichie (2011), entre outros.

Palavras-chave: Literatura. Identidade. Protagonistas negras.

Resumen: La obra Torto Arado (2019), de Itamar Vieira Junior, trae reflexiones sobre heridas que aún están abiertas y aún causan dolor por los problemas de la esclavitud y sus consecuencias, ya sea en el ámbito individual, cultural, político o ideológico. El hecho es que las políticas, los programas y todas las medidas contra la discriminación que enfrentan los efectos perversos de la colonización siguen presentes en la sociedad brasileña. Desde esta perspectiva, el trabajo en cuestión tiene como objetivo analizar la relación entre la (des) (re) construcción de la identidad de la mujer negra que pretende contar su propia historia, proveniente de otros lugares de enunciación que vienen impregnados de una visión eurocéntrica. Así, en la novela se considera en primer lugar la relevancia de la literatura como instrumento de resistencia en la lucha contra la injusticia racial y las desigualdades de género.

\footnotetext{
${ }^{1}$ Mestranda pelo Programa de Pós-Graduação em Letras: Estudos Literários da Universidade Estadual de Mato Grosso - UNEMAT. Porto Alegre do Norte, Mato Grosso, Brasil. E-mail: pacienteluzl@ gmail.com

${ }^{2}$ Doutor em Letras pela Pontifícia Universidade Católica do Rio Grande do Sul (PUCRS). Docente do Instituto Federal de Mato Grosso. E-mail: epaminondas.magalhaes@plc.ifmt.edu.br
} 
Luego, a partir de las narrativas de los protagonistas de la novela en cuestión, observa el camino recorrido por los personajes femeninos en la constitución de sus identidades. Finalmente, busca conocer las voces de la ascendencia que dan sentido a su existencia y el placer de (re) descubrir a una mujer segura y más fuerte. Las perspectivas teóricas que impregnan el estudio son los trabajos de: Spivak (2010), Stuart (2007), Edward (2001), Duarte (2005), Adichie (2011), entre otros.

Palabras-clave: Literatura. Identidad. Protagonistas negras.

\section{Introdução}

O romance Torto Arado (VIEIRA JUNIOR 2019) traz reflexões acerca das feridas que foram causadas pelas mazelas advindas do legado histórico escravista, e que ainda estão abertas trazendo opressão social, econômica, política, de gênero, raça e cultura. Nesse sentido, deixa claro que a abolição da escravatura ainda está inacabada e requer enfrentamento aos problemas causados pelas discriminações, agressões e humilhações que a mulher negra sofreu e sofre ainda hoje.

Nesse sentido é preciso contestar, escrever, ocupar espaços e ser visível em uma sociedade que não aceita a diversidade e insiste em apagar a história e os direitos de sujeitos legítimos e amparados por lei. Desse modo, desejam tão somente viverem plenamente como cidadãs, senhoras de suas vidas e suas histórias, com vozes que narram, que falam e agem com o conhecimento de quem vivenciou a exploração, o preconceito e a desumanidade colonial.

As Mulheres voltam o olhar para si, para recriar e (re) significar a suas imagens. Dessa forma, o foco dessa pesquisa é analisar o movimento de (re) constituir-se como mulher negra que fala por si e pelos seus, a partir da memória que fortalece a identidade da mulher afrobrasileira. Assim, ela vem para desconstruir estereótipos e reivindicar sua história sob uma nova perspectiva, rompendo com a ideia de acreditar numa história que outros contaram sobre você, sobre o seu povo, conforme alerta ADICHE (2011) ao falar sobre o perigo de uma história única.

Este artigo está dividido em três partes. A primeira aborda a literatura como objeto de resistência, a partir da subjetividade de escritoras (es) que trazem as suas vivências, suas vozes de outros lugares de enunciação, para serem ouvidas do ponto de vista da mulher negra, assim, elaboram seus textos literários em diálogo com aspectos das culturas e tradições afrobrasileiras. Mulheres que enfrentam o preconceito, seja ele racista, de gênero, ou de qualquer 
outra natureza. Com o objetivo de afirmarem-se como sujeitos de direito, donas de seus corpos e suas escolhas.

$\mathrm{Na}$ segunda parte, o assunto refere-se as identidades que as narradoras negras vão construindo ao narrar as suas histórias. Assim, elas continuam a história de luta e resistência de suas ancestrais e constroem uma nova trajetória, através de um projeto de emancipação coletiva. Dentre os diversos aspectos que o romance evidencia, estão os movimentos sociais que une e fortalece as mulheres como sujeitos femininos de direito, a partir do contexto trazido pelas relações familiares, as questões de raça, as tradições religiosas afro-brasileiras, os diálogos com o período escravista e seus reflexos.

E por fim, traz o protagonismo e o orgulho da mulher negra como agente central na construção da sua história, fazendo um diálogo do romance de Vieira Junior (2019) Torto Arado, com o texto "O perigo de uma história única" de Adchie (2011), e o poema "VozesMulheres", de Conceição Evaristo (2008), os quais revelam a trajetória de mulheres negras que viajaram nos caminhos da memória e colheram as vozes dos seus ancestrais que clamam por justiça no presente, na perspectiva da preparação de um futuro com melhores condições para si e para as próximas gerações.

As mulheres negras têm buscado dar resposta aos desafios da atualidade. Elas reivindicam o direito e a segurança para o seu povo, entendendo o racismo como um problema sistêmico e estrutural, que deve ser debatido em espaços de resistência. De modo que façam o enfrentamento a todo tipo de violência e de dificuldades que venham travar ao acesso às políticas públicas para as minorias. Nesse caso, torna-se fundamental refletir sobre a importância da literatura negra como uma ferramenta que fortalece o sentimento de pertencimento étnico.

Trata-se de conquistar cada vez mais espaço no cânone literário brasileiro, de forma que venha contribuir para a crescente produção e inclusão das literaturas minoritárias nos espaços culturais e sociais. De modo que seja possível outras vozes "falar por", que para (SPIVAK, 2010, p. 31) é fazer o deslocamento dos sujeitos marginalizados para o centro, em posição de protagonismo, que em os atos de falas possam serem representados por personagens da ficção literária, que permitam a inclusão de sua diversidade cultural e seu protagonismo histórico que nem os anos de escravidão conseguiram apagar. Portanto, ouçam as vozes e abram espaços para a mulher negra se reinventar. 


\section{A literatura como objeto de resistência para o fortalecimento da identidade}

No romance Torto Arado (2019), a África está bem representada, pois se o enredo da história não nega a escuridão dos porões dos navios, a fome, a escravidão e todo o sofrimento que ela causou, a tônica do romance é mostrar a riqueza cultural africana, e as suas diversas contribuições: as tradições tribais, étnicas e a vasta pluralidade linguística que contribuíram para a formação de um povo brasileiro multicultural. Mas que toda essa riqueza de diversidades tem sido negada pela imposição de uma única cultura, a eurocêntrica. Para Munanga (2012, p.7):

O ponto de partida do multiculturalismo é a existência, no seio de uma mesma sociedade, mesmo estado, nação, território geográfico etc., de mais uma cultura, uma comunidade (religiosa, linguística, cultural, étnica etc.). Além dessas comunidades que produzem culturas comunitárias, supõe-se a existência de uma única cultura nacional que se sobrepõe às outras.

Nesse sentido, percebe-se a necessidade de conhecer a sua realidade para ser um agente de transformação e, assim, compreender a partir da premissa de que a história não é natural, ela é uma construção das relações históricas produzidas pelas ações humanas. Desse modo faz-se necessário um enfrentamento a esse racismo sistêmico estrutural que vem sendo construído por mais de cinco séculos, e então, mudar essa situação de adversidades, por justiça social.

Para tanto, as ações afirmativas devem seguir um caminho seguro, como o apontado por Munanga (2012, p.10), que diz: “O essencial é reencontrar o fio condutor da verdadeira história do Negro que o liga à África sem distorções nem falsificações". Desse modo as protagonistas do romance trazem em suas narrativas as experiências que demonstram o autoconhecimento e o conhecimento do contexto no qual estão inseridas.

Assim, a literatura afro-brasileira é uma contra narrativa comprometida com a reescrita da história da mulher negra, a partir do ponto de vista da classe que foi subalternizada. Isso vale para o seu protagonismo na vida e na literatura. Seja como autora, seja como narradora. Ou ainda, na (re) constituição identitária, na inclusão histórico-social, ou como meio de denunciar e resistir as várias facetas do preconceito. Itamar Vieira Junior (2021), em uma entrevista, fala sobre a importância da literatura para entender o que se passa com o outro.

Quando a gente pega um livro para ler, a gente faz um trato com o autor e com as personagens. Durante algum tempo, vamos viver aquelas vidas. Isso é um poderoso instrumento de alteridade, de empatia. Eu acredito que, dessa forma, a literatura pode contribuir para que a gente imagine a vida de outras pessoas, se coloque na pele de 
outras pessoas, para poder entender a complexidade de suas vidas. (VIEIRA JUNIOR, 2021).

O olhar aqui presente tem por objetivo contextualizar as conquistas do lugar de fala emancipatória e identitária da mulher negra, ao projetar o caminho de resistência de várias gerações para se chegar a esse lugar, esse entendimento possibilita o fortalecimento da identidade, da autoestima, dos relacionamentos interpessoais de mulheres negras, que são frequentemente silenciadas pelo racismo.

Nesse sentido, os argumentos revelam a articulação indissociável entre literatura, memória e identidade. Sendo possível entender que uma se vale da outra para existir. A literatura se vale da memória para a constituição de tramas ficcionais no sentido de buscar fontes que embasam as representações da realidade; a memória se vale de obras literárias para sua perpetuação; e a identidade se vale das duas, pois as narrativas oferecem a possibilidade de reorganizar as experiências e de reavaliá-las.

O romance tem vários pontos de destaque que provocam o interesse e a curiosidade do leitor, entre eles a narrativa em primeira pessoa, sendo a narradora-personagem a protagonista que inicia a narrativa com lembranças de sua infância, uma menina negra, chamada Bibiana, tem 7 anos de idade, que conta quando e como ela e sua irmã Belonísia se machucam em um acidente enquanto remexem nos segredos guardados na velha mala da avó.

Quando retirei a faca da mala de roupas, embrulhada em um pedaço de tecido antigo e
encardido, com nódoas escuras e um nó no meio, tinha pouco mais de sete anos. Minha
irmã, Belonísia, que estava comigo, era mais nova um ano. Pouco antes daquele evento
estávamos no terreiro da casa antiga, brincando com bonecas feitas de espigas de milho
colhidas na semana anterior. Aproveitávamos as palhas que já amarelavam para vestir
feito roupas nos sabugos. Falávamos que as bonecas eram nossas filhas, filhas de
Bibiana e Belonísia. (VIEIRA JUNIOR, 2019, p. 13)

Para HALL (2006), a criança forma sua identidade ao longo do tempo por meio de processos inconscientes. No episódio citado, Bibiana traz a memória a construção da identidade, que se inicia na infância e sofre influência das referências com as quais ela irá se deparar. Entre essas referências das crianças negras estão presentes o preconceito e a discriminação racial de um país que traz o racismo em suas entranhas. E permeiam todo o processo de construção da identidade dos povos afrodescendentes brasileiros. Desse modo, torna-se de extrema importância viabilizar oportunidades significativas para a construção da subjetividade da menina negra, de sua autoestima e de sua formação crítica e reflexiva. 
São meninas, jovens e mulheres, e são outras que tem um vínculo com a história dos ancestrais, pois alguém viveu as experiências de seu tempo: um pai, um avô, uma avó ou um bisavô, são momentos que expressam a infância, a adolescência e a vida adulta de muitas gerações, elas são como âncoras que dão apoio a existência do mundo de cada um (a).

Gayatri Spivak (2010) afirma que a classe subalterna precisa de uma arma fundamental para sua emancipação, que é a voz. Essa voz é a sua expressão reivindicatória e uma arma para sua organização enquanto classe, pois sem voz, não existe uma classe, apenas um aglomerado de seres à margem. Assim, a existência de produções de naturezas diversas, reivindicando seu espaço, é um meio de reivindicação, e de visibilidade da mulher negra.

A partir desta perspectiva, o escritor utilizar-se do romance para compartilhar as vozes dessas mulheres, e assim, quebrar paradigmas ao utilizar-se da escrita literária para abrir um espaço que historicamente lhes fora negado, e que atualmente são raros, mas estão sendo conquistados com luta, suor e sangue, e desse modo, vão desconstruindo com os estereótipos impostos por uma visão eurocêntrica carregada de preconceitos: negra doméstica, mulata objeto sexual, capacidade intelectual inferior, comparados aos animais irracionais.

É preciso mapear esses preconceitos construídos historicamente, entendê-los como tática da estrutura racista, para então subvertê-los, descartar esse tipo de representação, criar e principalmente pautar nos mais diversos espaços culturais, livros escritos por pessoas negras para que ganhem cada vez mais espaço no mercado, e leitores possam se identificar com mais obras e ampliar seus pontos de vista.

Essa escrita subversiva é uma resposta aos anos de agressão e humilhação que o povo negro, especificamente, a mulher, que sofreu e ainda sofre com mazelas da escravidão. Duarte (2005), fala sobre Literatura e compromisso, ele cita Plabo Neruda e a atuação política presente em seus poemas "reveste sua poesia com os tons de hino político e com cores da indignação e da chamada resistência..."

O romancista tece uma narrativa distante dos padrões europeus, é uma proposta de ruptura com o imaginário ocidental acerca geral, incluindo a literatura infantil, distante de suas experiências, nas quais as crianças nascem em palácios com títulos de princesas, cercadas por serviçais. Enquanto o mundo ficcional de Bibiana e Belonísia acontece em uma comunidade quilombola. E lá não tem palácios, nem a realeza, e nem tão pouco, as protagonistas são chamadas de princesas. 
Lajolo e Zilberman (2007, p. 68), afirmam que a literatura infanto juvenil brasileira sofreu muita influência das narrativas europeias. Assim, parte das histórias contadas no Brasil advém do folclore europeu e não absorveram quase nenhuma cultura do povo negro brasileiro, bem diferente do que acontece com as crianças de Água Negra, que descrevem suas brincadeiras assim: "no terreiro da casa antiga, brincando com bonecas feitas de espigas de milho colhidas na semana anterior. Aproveitávamos as palhas que já amarelavam para vestir feito roupas nos sabugos. Falávamos que as bonecas eram nossas filhas...” (VIEIRA JÚNIOR, 2019, p. 9)

Distante, bem distante do cânone literário europeu, existe o mundo literário do romance Torto Arado, que abre possibilidades para novas histórias, uma vez que suas personagens são providas de suas vivências, elas não aceitam mais serem considerados incivilizados, ou serem chamados de selvagens. Nada disso corresponde a representação cultural do povo negro, assim como, os contos de fadas não representam as suas subjetividades.

Dessa forma, essa história ficcional não poderia estar desconectada de um contexto que faça sentido para quem compartilha dos sentimentos e sensações das personagens, e que por elas, possibilitam ao leitor o sentimento de pertencimento a uma cultura que se identifica com a sua. Portanto, é importante considerar a literatura como lugar de afirmação e singularização dos sujeitos que se conectam a uma história que é significativa e tem conexão com a suas vivências.

\section{Mulher negra quilombola contando sua própria história}

As mulheres que encontramos narrando as suas histórias no romance têm acesso livre a suas existências, falam das próprias experiências, e contam as suas histórias sob as suas perspectivas. Já não são apenas olhadas, elas se olham também; não são figurantes, são protagonistas, elas narram e, por meio de suas vozes são ouvidas.

Ali, pude observar, as mulheres são lideranças políticas, o que me parece um paradoxo, já que vivemos numa sociedade profundamente patriarcal. Daí o deslocamento dessa história para o corpo e a vida das mulheres; somente elas poderiam narrar a história da terra, onde sua comunidade vive. (VIEIRA JUNIOR, 2020).

Em uma entrevista na Revista Radis (2021) perguntaram a Itamar, "Mas por que são mulheres as narradoras?" Ao que ele responde: "Nesse meu caminhar de 15 anos entre comunidades e povos do campo, eu posso lhe garantir que, principalmente em comunidades quilombolas, $70 \%$ das lideranças são mulheres". Em um outro trecho da entrevista, observa: 
"Vi nesse narrar tão familiar, tão simples, um poderoso instrumento estético para contar uma história literária, para fazer literatura". (VIEIRA JUNIOR, 2021). E foi o que ele fez ao propiciar uma voz autoral as personagens, dando visibilidade textual e articulação discursiva para elas narrarem as suas histórias, como faz Bibiana.

Cresci em meio às crenças de meu pai, de minha avó, e mais recentemente de minha mãe. Os objetos, os xaropes de raízes, as rezas, as brincadeiras, os encantados que domavam seus corpos, tudo era parte da paisagem do mundo em que crescíamos (VIEIRA JUNIOR, 2019, p. 50).

Fala das experiências que já são vividas faz muito tempo, sem o olhar de quem fala de fora, do exótico, do desconhecido que facilmente caí no abismo dos estereótipos.

Através dessas vozes é possível visualizar o período e a dor da diáspora negra, em que homens e mulheres negras foram deslocados forçosamente de suas origens identitárias: a terra, a língua, a religião, enfim, a cultura, em condições sub-humanas. E desde então, lutam pela dignidade a que todas (os) tem direito. Belonísia retrata essa realidade, ao descrever o parto em que seu pai veio ao mundo por sua vó Donana.

Meu pai havia nascido quase trinta anos após declararem os negros escravos livres, mas ainda cativo dos descendentes dos senhores de seus avós. Minha avó, Donana, havia dado à luz ao filho José Alcino em meio a uma plantação de cana na Fazenda Caxangá. Ele nasceu no meio de um charco, porque não haviam permitido que sua mãe deixasse de trabalhar naquele dia. (VIEIRA JUNIOR, 2019, p.146).

As vozes dessas mulheres que passaram por gerações de atrocidades, as quais, eram obrigadas a obedecer aos seus donos que exerciam poderes sobre elas. Entretanto, essa obediência não deve ser entendida como passividade, mas sim como resistência, afinal, era preciso sobreviver para que uma nova geração dessa continuidade à luta pela liberdade. E essa luta é de todas que lutam por justiça e por espaço para que essas vozes sejam ouvidas. Segundo Spivak (2010), a tarefa do intelectual pós-colonial deve ser a de criar espaço por meio dos quais o sujeito subalterno possa falar para que, quando ele ou ela o faça possa ser ouvido (a).

Nessa perspectiva, Torto Arado, traz três vozes femininas, para contar a história de três gerações de mulheres negras que são protagonistas e protagonizam outras figuras femininas que como elas, têm histórias fortes, marcadas pela resistência a qualquer tipo de opressão. Pois reconhecem que as opressões da classe dominante têm silenciado por séculos essas vozes. Assim faz-se necessário abrir espaços que tragam essas vozes de resistência, para que elas possam ecoar bem forte e serem ouvidas. 
O livro foi dividido em três partes, sendo que cada uma delas é narrada por uma personagem feminina, a primeira parte: "Fio de Corte", por Bibiana, traz a metáfora da faca que corta e silencia. A segunda: "Torto Arado", narrada por Belonísia que mistura-se à terra tortamente arada; e por último: "Rio de Sangue", narrada por uma entidade do Jarê, chamada Santa Rita Pescadeira. No roteiro da história elas retratam a violência da escravidão, violência no campo na luta pela terra, e ainda, violência contra a mulher.

A narradora-personagem, Bibiana inicia a estória com uma lembrança de infância, que tem a faca como símbolo de resistência, justiça, defesa, mas também e um prenúncio de violências que permeia toda a narrativa e aparece pela primeira vez nas palavras de Bibiana : "Quando retirei a faca da mala de roupas, embrulhada em um pedaço de tecido antigo e encardido, com nódoas escuras e um nó no meio, tinha pouco mais de sete anos.”( p.13). Nesse episódio, as irmãs Bibiana e Belonísia acabaram se ferindo com a faca da avó.

A segunda parte é narrada por Belonísia, personagem que perdeu a sua língua no acidente com a faca de Donana. Após um tempo casa-se com o vaqueiro Tobias, que passou a torturá-la diariamente com xingamentos e deboches a sua deficiência. Nunca chegou a ser espancada, não por respeito, mas pela sua coragem: "Antes que qualquer homem resolvesse me bater, lhe arrancaria as mãos ou cabeça, que não duvidassem de minha zanga." (JUNIOR, 2019 p. 121). Tobias tinha conhecimento da sua determinação para se defender. Essa e outras histórias no romance, alertam para a violência contra as mulheres do campo, na maioria das vezes, praticadas por seus companheiros dentro de casa.

A terceira narradora representa uma entidade chamada Rita Pescadeira, ela relata a sua história e outras histórias. Entre elas, a da barbárie do período escravagista nunca cessou, apenas se remodelou: "Vi senhores enforcarem seus escravos como castigo[...] Acudi uma mulher que incendiou o próprio corpo por não querer ser mais cativa de seu senhor." (JUNIOR, 2019, p. 207). Percebe-se que mesmo frente à crueldade, a resistência está presente.

As narrativas seguem do começo ao final, a trajetória da faca ancestral de Donana, sendo usada na maioria das vezes em nome da justiça. Sua última missão foi cumprida pelas mãos duplas da encantada/cavalo, ao se vingar da morte de Severo, esposo de Bibiana. Ele foi vítima na luta por um pedaço de terra. Assim a história termina com a frase: "Sobre a terra há de viver sempre o mais forte." (JUNIOR, 2019, p. 262).

A história da família de Donana, a avó paterna e matriarca da família, carrega o legado de uma rica tradição cultural do sertão brasileiro, onde se misturam as crenças, lendas, religião, 
trabalho análogo à escravidão, sofrimento, violência, gratidão, ancestralidade e, principalmente o amor pela família e o amor pela terra. Nesse contexto, evidencia-se um mundo de tradições valorosas, que por séculos tem sido alvo de tantas injustiças, e como mudar essa realidade? Será que por esse caminho que Hall (2003) indica?

Portanto, não é uma questão do que as tradições fazem de nós, mas daquilo que nós fazemos das nossas tradições. Paradoxalmente, nossas identidades culturais, em qualquer forma acabada, estão a nossa frente. Estamos sempre em processo de formação cultural. A cultura não é uma questão de ontologia, de ser, mas de se tornar. (HALL, 2003).

Ao longo do enredo pode-se acompanhar as transformações que ocorrem na vida das personagens, ao passarem pelas injustiças da escravidão, a luta no campo, os saberes que nascem da terra, os saberes que vem da educação escolar. Tudo isso se conecta com os leitores que é perpassado por essas vozes, seus relatos e sua força. E assim, muitos deles se identificam com Donana, Bibiana, Belonisia, Salú... Entre outras personagens.

A família de Donana, imersa no interior do sertão baiano, representa muitas famílias que vivem pelas terras brasileiras. As suas vozes perpassam pelas histórias narradas por Bibiana, Belonisia e Rita Pescadeira, vozes que saíram do silêncio e se juntam a outras vozes, que se lançarão cada vez mais longe em uma rede de evocação e escuta. Carvalho (2008), argumenta sobre a importância de ouvir o outro:

E só vou deter-me agora aqui num dos aspectos que enunciei: ouvir ainda esse "outro" enquanto ele ainda existe [...] ainda existe mesmo? [...] E acrescenta: existe ainda sim, em certas partes do mundo como aquela de onde estou a sair e me mobiliza de há décadas a esta parte a atenção total [...] e se me empenho agora aqui em fazer campanha para que esse "outro" seja ainda tido em conta e ouvido. (CARVALHO,2008, p.66)

Nesse sentido, "ouvir ainda esse "outro", significa contribuir para a confluência de histórias pessoais e coletiva de desejos, sofrimentos, experiências do cotidiano, tradições, memórias e sonhos. Nesse contexto o mais importante é dar-se a aprender do outro e com o outro. Aprender sobre a autênticas histórias que foram vivenciadas pelos seus ancestrais. E assim, rejeitar e questionar a autenticidade da história contada pelos colonizadores. E então, compreender e fortalecer as identidades das mulheres negras.

O romance retrata a população com quem Itamar teve contato no trabalho, ele representa-os, quando fala na entrevista: "trocaria todos os meus títulos acadêmicos, eu trocaria tudo o que aprendi na universidade, pelo que aprendi entre eles. Porque é uma forma de narrar, de experienciar a vida" (VIEIRA JUNIOR, 2021). Assim, ele se deixa ser perpassado pelas 
vozes de "outros", e assim, torna possível que histórias reais se transforme em ficção para exercer o poder transformador e humanizador da literatura.

De modo que o lugar de fala que o autor inclui nas narrativas é a consciência coletiva dos sujeitos nas lutas por seus direitos. Traz a esperança de uma liberdade desejada por esse grupo que se reconhece e entende em qual espaço se encontra

Traz a esperança de uma liberdade desejada que se torna real. Não existe nesse cenário o silenciamento das vozes. Na verdade, elas se pertencem e se fortalecem ao se encontrarem com diversas vozes de Bibianas, Belonísias, Zecas Chapéu Grande, Salustianas, Donana e outras (os) protagonistas, tecendo histórias de esperança, de luta por respeito e reconhecimento por toda contribuição dada para a formação da sociedade brasileira.

\section{Da descoberta ao orgulho de ser mulher negra quilombola}

A única história cria estereótipos [...] mostre um povo como uma coisa, como somente uma coisa, repetidamente, e será o que eles se tornarão... ADICHIE (2009)

Chimamanda Ngozi Adichie, escritora nigeriana, em uma palestra falou sobre "O perigo de uma única história” (2009). Quando completou dezenove anos, deixou a Nigéria e mudouse para os Estados Unidos para estudar. A partir de várias experiências vivenciadas em um país com uma cultura diferente, ela chega à conclusão que não se reconhecia conscientemente como africana. Falou, que sua colega de quarto pensou que ela não sabia como usar o fogão. Ficou muito impressionada ao perceber que mesma sem conhecê-la, ela já sentia pena de sua condição de ser africana. ADICHIE (2009):

[...] ela sentiu pena de mim antes mesmo de ter me visto. Sua posição padrão para comigo, como uma africana, era um tipo de arrogância bem-intencionada, piedade. Minha colega de quarto tinha uma única história sobre a África. Uma única história de catástrofe. Nessa única história não havia possibilidade de os africanos serem iguais a ela, de jeito nenhum. Nenhuma possibilidade de sentimentos mais complexos do que piedade. Nenhuma possibilidade de uma conexão como humanos iguais (ADICHIE, 2009, pp. 02).

Com o passar do tempo, ela foi percebendo o que estava acontecendo, lembrou-se de um episódio que se passara com ela ao visitar a casa do garoto chamado Fide. Ele é filho de uma funcionária de sua mãe que trabalhava em sua residência. Lembra da fala de sua mãe durante uma refeição. (ADICHIE,2011)

Termine sua comida! Você não sabe que pessoas como a família de Fide não tem nada? Então eu sentia uma enorme pena da família de Fide... fomos visitar a sua aldeia e sua mãe nos mostrou um cesto com um padrão lindo, feito de ráfia seca por seu irmão. Eu fiquei atônita! Nunca havia pensado que alguém em sua família pudesse realmente criar alguma coisa. ADICHIE (, 2011, p. 52). 
Quando as histórias endossam os discursos coloniais, com palavras, com pequenas frases e histórias, enfraquecem a resistência que combate ao preconceito, demonstra despreparo para o enfrentamento às injustiças sofridas pelas minorias que foram excluídas historicamente. Nesse sentido, silenciar-se é perigoso, mas, reforçar o discurso colonial é mais perigoso ainda. No momento, faz-se necessário uma ruptura com o silêncio imposto pelo sistema escravista colonial.

Nesse contexto, todas as contribuições africanas, sua arte, a cultura tradicional, a oralidade e escrita, as crenças, os rituais, os costumes, a sabedoria ancestral - tudo isso que sempre foi transmitido de geração para geração, e que ainda se mantêm pelo vínculo da memória deve ser reivindicado. E a partir do momento histórico atual, ocupar espaços de poder que possa modificar o substrato histórico-social e promover o desmonte das narrativas racistas criando nossas próprias histórias, a partir da diversidade de práticas e linguagens de origem africanas.

Assim, para além do preconceito e da luta contra ele, trata-se de buscar caminhos positivos de reconhecimento e de reconstrução da identidade da mulher negra por meio de redes de subjetividades, para serem executadas em espaços de luta. Sendo a literatura uma arma possível para enfrentar as injustiças instituídas.

Desse modo, o romancista de Torto Arado protagoniza uma literatura afirmativa que traz a experiência e a historicidade dos povos africanos, que tiveram a sua rica cultura milenar rebaixada, excluída e apagada, por séculos. Ele põe-se em movimento o uso da língua, das narrativas que falam de outros mundos possíveis, as suas personagens falam da representação do seu mundo, do valor de cada experiências com riqueza de detalhes, como a narrativa de Bibiana.

Cresci em meio às crenças de meu pai, de minha avó, e mais recentemente de minha mãe. Os objetos, os xaropes de raízes, as rezas, as brincadeiras, os encantados que domavam seus corpos, tudo era parte da paisagem do mundo em que crescíamos (VIEIRA JUNIOR, 2019, p.50)

É importante ressaltar que o romance abre espaço para que as vozes das protagonistas possam contar as suas histórias de trabalhadoras rurais que tomam posse de um lugar de fala que lhe é conhecido, e com determinação recuperar as vozes silenciadas dos seus antepassados. faz conhecida a história da escravidão, que continua nos latifúndios de todo o Brasil. Sendo essa, uma representação que se baseia em situações reais de família de 
descendentes de escravos que vivem em fazendas, seja em Chapada Diamantina, no interior da Bahia, ou em outros lugares, pagando com o trabalho exaustivo o direito de moradia e alimentação.

É importante detectar e conhecer a estrutura da colonização nas suas diversas facetas, e estratégias degradantes em diferentes épocas. E para luta contra ela e importante problematizála em história de forma crítica e contextual, ao afirmar que os discursos são historicamente construídos intencionalmente. Frente a esses desafios é preciso desafiar e contestar realidades de desigualdades instituídas. E evidenciar a representatividade das mulheres negras que se orgulham da cultura de seu povo.

O olhar para a ancestralidade faz lembrar e manter viva a memória, sendo ela um caminho de passeio livre, que não escraviza, ao contrário, ela alerta e liberta. Ele está sendo muito explorado por escritoras (es) que estão comprometidos com as histórias que lhes foram negadas. Evaristo (2009) com o poema Vozes-mulheres, trilha por esse caminho e se ressignifica, e abre caminhos para a construção identitária de mulheres que necessitam desse encontro para que tenham suas de vozes ouvidas.

\begin{abstract}
A voz de minha bisavó ecoou criança nos porões do navio ecoou lamentos de uma infância perdida [...] A voz de minha avó ecoou obediência aos brancos-donos de tudo [...] A voz de minha mãe ecoou baixinho revolta no fundo das cozinhas alheias [...] A minha voz ainda ecoa versos perplexos com rimas de sangue [...] A voz de minha filha recolhe todas as nossas vozes [...] A voz de minha filha recolhe em si a fala e o ato [...] O ontem - o hoje - o agora. Na voz de minha filha se fará ouvir a ressonância o eco da vida-liberdade. (EVARISTO, 2009).
\end{abstract}

As vozes plurais que ecoam no poema, representam as gerações que passaram pela escravidão, sendo submetidos aos sofrimentos e mazelas da desumanidade que ela provocou. $\mathrm{Na}$ trilha da memória relembram os momentos históricos de cada geração que foi escravizada. Nessa perspectiva o romance e o poema se conectam, e passam a mensagem de que a resistência, e mesmo a submissão como estratégia de sobrevivência, foram lutas travadas por uma coletividade de vozes que mantiveram o sentimento de pertencimento.

Assim as personagens recuperam as vozes silenciadas dos seus antepassados e se fortalecem para lutar por mudanças. Bibiana luta pelo direito à terra e por condições melhores para a sua comunidade em Água Preta. Belonísia, mesmo tendo perdido a capacidade de falar fluentemente, não perde a sua autoconsciência ao expressar sua narrativa de amor pela terra, assim como, de mostrar a sua coragem para enfrentar a dureza do sertão. 
E por fim, a voz de Rita Pescadeira que ultrapassa a dimensão de tempo e espaço e de forma emblemática e contagiante, sendo ela uma entidade onisciente, revela os segredos de várias gerações e faz denúncias aos maus tratos da escravidão. (VIEIRA JUNIOR, 2019, p 180) Os donos já não podiam ter mais escravos, por causa da lei, mas precisavam deles. Então, foi assim que passaram a chamar os escravos de trabalhadores e moradores.

\section{Considerações finais}

Nesse artigo, foi possível perceber a importância da literatura e a história se apoiando mutuamente, para desconstruir e problematizar os discursos eurocêntricos. E assim, apontar para a discussões sobre a necessidade de trabalhar outro olhar sobre a colonização. Nesse sentido fica claro que é preciso romper com a língua colonial, não é possível das palavras que construíram o império colonial: explorar, exterminar, conquistar, dominar e escravizar. Quantas culturas produzidas por diversos povos extraordinários foram extintas, ou colocados a margem pela ambição de exploradores desumanos.

A literatura escrita e oral pode transformar a história da África que em parte foi negada, ou foi contada e escrita pelo ponto de vista do colonizador. Assim como, é fundamental para que ocorram mudanças, o cumprimento das leis constitucionais que garantem os direitos às diferenças. É a partir desse contexto que a resistência negra brasileira luta pela implementação de políticas que promovam o respeito e ao reconhecimento de suas histórias. E então, desconstruir dia a dia, a história de dominação e opressão das Áfricas e das Américas pelo colonizador.

A África é um continente, isso pode até parecer óbvio, mas não é. Muitas pessoas falam do continente como se ele fosse uma região homogênea habitada por um único povo, desconhecem as diversas origens, línguas e etnias dos povos africanos. Esse apagamento intencional da sua diversidade étnica, cultural e histórica tem sido repetida por século, quiseram fazer acreditar que lá existe apenas fome, pobreza e uma terra seca. Essas mentiras têm sido um desastre e tem causado o extermínio de muitos povos.

Entender que a história da África não começa aqui no Brasil, e nem começa com a escravidão. Saber outras histórias fora do domínio do colonizador, ouvir outras histórias dos africanos que vieram para o Brasil, e dos que ficaram na África. Saber por que aconteceu a colonização... Como vieram para as em terras brasileiras? Quais são as suas histórias? E muitas 
outras perguntas que não foram feitas... Porque foram dispersas, ignoradas, e infelizmente, muitas foram destruídas. Mesmo se tivessem todas essas respostas, não diminuiria todo o sofrimento, e nem isentaria as injustiças cometidas.

É possível ter um pouco do que foi de volta? Com certeza, só é preciso se disporem a (re)conhecer. Nesse percurso de volta, acredita-se que será um (re)encontro com uma parte da história que foi negada. Nunca será um retorno ao lugar mesmo lugar, cada um viveu o seu momento "não estamos em casa", conforme frisa Iain Chambers, citado por Stuart Hall (2003, p.27) "Não podemos jamais ir para casa, voltar a cena primária [...] pois só podemos conhecer o passado, a memória, o inconsciente através de seus efeitos”.

Portanto, o romance retrata as relações interpessoais e a coragem das protagonistas, o que contribui para o fortalecimento da identidade cultural das personagens, sendo justamente por assumirem uma posição de combate as adversidades que encontram pela frente, que elas estão firme no propósito de conquistarem os seus lugares de direito.

\section{Referências}

ADICHIE, Chimamanda Ngozi. O perigo de uma história única. São Paulo: Companhia das Letras, 2019.

CARVALHO, Ruy Duarte. Tempo de ouvir o 'outro' enquanto o "outro" existe, antes que haja só o outro... Ou pré - manifesto neo-animista. Buala. Disponivel em $<$ https://www.buala.org/pt/ruy-duarte-de-carvalho/tempo-de-ouvir-o-outro-enquanto-o-outroexiste-antes-que-haja-so-o-outro-ou-p>. Acesso em 06 de julho de 2021.

EVARISTO, Conceição. Poemas da recordação e outros movimentos. Belo Horizonte: Nandyala, 2008.

HAIDER, Asad. Armadilha da identidade. Raça e classe nos dias de hoje. São Paulo: Veneta, 2019.

HALL, Stuart. Da diaspora: Identidades e mediacoes culturais / Stuart Hall; Organizacao Liv Sovik; Traducao Adelaine La Guardia Resende let all. - Belo Horizonte: Editora UFMG; Brasilia: apresentacao da UNESCO no Brasil, 2003.

LAJOLO, Marisa; ZILBERMAN, Regina. Da matriz europeia ao folclore brasileiro. In: Literatura infantil brasileira: histórias e histórias. 6. ed. São Paulo: Ática, 2007. 
MUNANGA, Kabengele. Negritude e identidade negra ou afrodescendente: um racismo ao avesso? In: Revista da ABPN, v. 4, n. 8, jul.-out. 2012. Disponível em: https://abpnrevista.org.br/index.php/site/article/view/246/222. Acesso em: 05 de jan. 2022.

PAZ, Octavio. O arco e a lira. Trad. Ari Roitman e Paulina Wacht. São Paulo:Cosac Naify, 2012.

SAID. Edward Wadie. Reflexões sobre o exílio e outros ensaios, SP: Editora Companhia das Letras, 2001.

SPIVAK, Gayatri Chakravorty. Pode o subalterno falar? Tradução de Sandra Regina Goulart Almeida, Marcos Pereira Feitosa, André Pereira Feitosa. Belo Horizonte: Editora UFMG,2010.

VIEIRA JUNIOR, Itamar. Torto arado. São Paulo: Todavia, 2019.

Depoimento. Texto de: Júlia de Miranda. 2020.

Entrevista: "Há muita história soterrada" [abr. 2021]. Entrevistadora: Ana Cláudia

Peres. 2021. Entrevista concedida a Radis. 